\title{
Itinerario
}

http://journals.cambridge.org/lTI

Additional services for Itinerario:

Email alerts: $\underline{\text { Click here }}$

Subscriptions: $\underline{\text { Click here }}$

Commercial reprints: $\underline{\text { Click here }}$

Terms of use : $\underline{\text { Click here }}$

\section{Situating Science in Global History: Local Exchanges and Networks of Circulation}

\author{
Lissa Roberts \\ Itinerario / Volume 33 / Issue 01 / March 2009, pp 9 - 30 \\ DOI: 10.1017/S0165115300002680, Published online: 11 January 2010 \\ Link to this article: http://journals.cambridge.org/abstract_S0165115300002680 \\ How to cite this article: \\ Lissa Roberts (2009). Situating Science in Global History: Local Exchanges and \\ Networks of Circulation. Itinerario, 33, pp 9-30 doi:10.1017/S0165115300002680 \\ Request Permissions : $\underline{\text { Click here }}$
}




\title{
Situating Science in Global History \\ Local Exchanges and Networks of Circulation
}

\author{
LISSA ROBERTS*
}

In response to increasing academic interest, Cambridge University Press launched a new journal in 2006, entitled the Journal of Global History. To inaugurate the endeavour, the editors asked economic historian Patrick O'Brien to write an introductory essay to serve as a prolegomenon for this newly invigorated field of study. O'Brien began by noting that it is no mere coincidence that interest in global history should be growing, given the global challenges entailed in current-day economic, political and environmental issues. From this perspective, we might take "global history" to refer both to the field's geographical reach and its attempts to relate a global range of seemingly diverse phenomena. Both understandings require us to stretch beyond the narrow specialisms in which we were trained and invite increasing willingness to collaborate. Along these lines, O'Brien applauded those historians who have reached outside their own discipline to draw on the insights and methods of the natural sciences, as well as natural scientists whose work is shedding new light on historical development. In his words:

...renewed concern with the evolution of human interactions with nature attracts biologists, geologists, botanists, climatologists, palaeontologists and epidemiologists into history. Their deeper comprehension and, latterly, the modern modes they have adopted for the lucid communication of scientific knowledge pertaining to these all-important connexions, are being fed back into history...Science recognises no borders and has always striven for universal understanding. That is why the integration of its empirically validated theories and insights into long-neglected connexions between human and natural histories has become widely accepted as a necessary basis for comparative history on global and more local scales. ${ }^{1}$

We might see O'Brien's call at least partially as the continuation of a tradition set out by the second generation Annales historian Fernand Braudel, who built his magisterial study of the Mediterranean world on a recognition of the long-term importance of climatalogical, geographical and demographical factors. ${ }^{2}$ But for all the insights that might be gained by mining the evidential fields of natural scientific inquiry, one cannot help but be struck by the essentially ahistorical character of 
claims such as O'Brien's statement that "[s]cience recognises no borders and has always striven for universal understanding".

A starting point for this essay is that the achievements of modern science must not blind us to the complex history whereby its institutions, practices and visions of nature came both to be shaped by, and to have a formative impact on, the global context in which they developed. ${ }^{3}$ For all its practical power, in other words, science is a historical phenomenon, one that is simultaneously a constructive element and a product of more general history on a global scale. This means that historians of science and historians interested in broader developments, encounters and interactions situated around the globe need to find each other and engage in a mutually beneficial conversation. In fact, this is already happening; topics such as "science and empire" have been on the agenda for a number of years already. ${ }^{4}$ But recent methodological developments have made it especially worthwhile to take stock of just how intertwined global history and the history of science are. For in place of a view of science as the West's gift to the world or histories that focus on western science primarily as a tool of imperialist domination, a dynamically balanced approach is emerging which seeks to highlight the productive role played by globally situated intercultural exchanges in the history of science and history more generally, while simultaneously recognising the asymmetrical character of the conditions that often attended such encounters.

For such an approach to be successful, it must attend to and connect two seemingly different orientations: the specifically local character of individual encounters and the increasingly global networks that both afforded and attributed meaning to the conditions and outcomes of these local exchanges. Together, they promise to help us construct a historical map that is simultaneously extensive in scope (linking both various parts of the globe and various aspects of material, cultural and geopolitical development) and intensive in detail. Along the way, they further promise to help us recognise that "the evolution of human interactions with nature", as O'Brian puts it, has always involved more than what can be revealed by the apparently objective findings of modern science. For while the character and meaning of human behaviour has a highly complex and globally variegated history, the same must be said for "nature". This is not only true in the sense that pristine nature, untouched by human intervention, became an increasingly rare phenomenon as history progressed. It is also true in the sense that human definitions and interpretations of, as well as attitudes toward "nature"-that is, human experience of "nature"-are not consistent across time and space. All these points have to be factored into an understanding of both the conditions and meaning of such interactions.

Terminology can be helpful in constructing a grid upon which to sketch a map that integrates the history of science with global history in a way that highlights both local exchanges and global networks, as well as their formative interactions. The primary terms explored in this essay and which provide the analytical backbone for this special issue are "contact zone", a term first developed by Mary Louise Pratt, and "circulation", a term that has gained increasing currency in both global history and the history of science. ${ }^{5}$ Together they link historical concerns with occurrences at the local level to concerns with the global networks of which these sites are an interactive part. In what follows, these points are fleshed out in three sections. The first 
offers a selective (largely Anglo-American) history of how the concept "circulation" came to be transformed from a shorthand expression for the inevitability of western dominance and (implied) superiority to a tool for redressing such an imbalanced view of global relations. The second section focuses on the ways in which "circulation" is currently being used, especially in the history of science, both to offer an account of scientific development that is sensitive to the constitutive importance of local exchanges and travel throughout the world, and to suggest the value of more closely integrating the history of science with global history. An examination of how best to investigate local sites of encounter and exchange- "contact zones" if you will-forms the heart of the third section. Here it becomes evident that phrases such as "think globally, act locally" are far more than empty clichés. For, as the conclusion reiterates, it turns out to be the uniquely complex characters of contact zones around the globe that form the bedrock of both modern science's apparently universal validity and its historical link to material progress.

\section{From Diffusion to Circulation}

It is a simple but powerful truism that histories tell us as much about the time and place in which they were written as about their ostensible subject matter. What should we make, then, of the late nineteenth-century British historian and apologist for imperialism John Robert Seeley's concern that his colleagues were growing myopic? In his famous work of 1883, The Expansion of England, Seeley wrote that too many historians seemed fixated on "mere parliamentary wrangle and the agitations about liberty, in all which matters the eighteenth century [the chronological focus of Seeley's book]... was but a pale reflection of the seventeenth. They do not perceive that in that century the history of England is not in England but in America and Asia". Further, he noted, if historians are indeed charged with charting development and change over time, it is crucial that they recognise that "the expansion of England involves its transformation". ${ }^{6}$ Historical transformation at the centre was thus causally linked, Seeley argued, to developments far from home. This view was shared by influential contemporaries, which provides us with important interpretive insight. As Victorian politicians such as Joseph Chamberlain took pains to publicise, it was the colonies that stoked England's rise to greatness-providing raw materials for its industrial growth and a global laboratory in which to demonstrate the civilised and progress-oriented nature of its culture. ${ }^{7}$ The causal relation of which Seeley wrote, in other words, was a circular one in which England was nourished by its empire so as to nurture the empire's social and cultural development.

This vision of circulation, governed by a perspective that put European industrial might and claims of cultural superiority at the centre of a progress-oriented path to the future, dominated mainstream science, politics, and history writing in the West until at least the 1960s. In the United States, it was fostered on countless university campuses where courses on the History of Western Civilisation were taught as an increasingly compulsory part of college curricula since the first decade of the twentieth century. These courses showcased a Eurocentric historical tradition to which American history and culture were appended, described by at least one influential historian as a tradition that traced "the evolution of freedom". ${ }^{8}$ On one hand, 
they tended to sport the rhetoric of objectivity, claiming to describe the march of history in neutral tones. On the other hand, the story they generally told was built on a double-barrelled narrative of moral and material progress. As a post-war review of Columbia University's curriculum put it:

Through such a study of our past, values emerge: that we live in a free society in which the spirits of justice, love, and scientific inquiry have been the touchstones to social invention; that in such a society the individual has laboured to achieve freedom from an arbitrary authority (whether ecclesiastical or political); and that in a climate of experimental science, technology, and liberal-capitalist institutions, man seeks to shape his world to achieve welfare for himself and for constantly growing numbers of the human race. ${ }^{9}$

The prevalence of such courses was supported by the publication of a number of "suitable" textbooks, the most successful of which was Robert R. Palmer and Joel Colton's History of the Modern World. ${ }^{10}$ Through the medium of its seemingly neutral narrative, Palmer and Colton's text helped standardise the vision enunciated above for a long generation of college students who read it (or similar texts) as part of their university education both in the United States and abroad. The role that science played in this drama of increasing welfare and enlightenment was clearly spelled out in the seventh chapter. "The scientific view of the world" exposed liberal arts majors to what historians Andrew Cunningham and Perry Williams have since labelled the "old big picture", in which the seventeenth century saw the simultaneous birth of modern science and the institutions that would support its subsequent translation into intellectual and industrial progress. Even today, the text's publishers advertise this chapter as explaining that in the seventeenth century

...science became modern. Scientific methods were defined, and scientific knowledge was increasingly applied practically...Scientific breakthroughs and new knowledge of the world outside Europe...led to a questioning of traditional beliefs. Science also influenced political theory, which embraced the philosophy of natural law. Human beings were considered rational, and states were subjected to the rigors of reason as well. The faith in science, progress, reason and rationality would fuel the cultural revolution of the Enlightenment...11

Small wonder, given this view of the historical power and progress of science, that influential figures such as Harvard University President James Bryant Conant pushed for the establishment of history of science courses as a way to introduce university students (the leaders of the future) to a subject that too often seemed forbiddingly difficult and distant. Hence the Harvard Case Studies in the History of Science were developed and first used in a university course that Conant chose himself to teach in 1949. Though with significant local variation, a comparable vision led to the establishment of a history of science program at the other Cambridge, advertised by the work of Herbert Butterfield, and spearheaded by the efforts of scientists-turned-historians Joseph Needham and Walter Pagel. ${ }^{12}$

If this were only a story of developments within Anglophone academia, the impact might arguably have been of limited interest. But the presence of similar views and trends in the fields of American science policy and foreign relations set 
the stage for consequences of global reach and significance. It is beyond the scope of this essay to discuss the role played by Conant's good friend Vannevar Bush in steering American science policy both during and after World War II, including efforts to tie academic science more closely to the military and industry in peacetime as well as in war, which led among other things to the establishment of the American National Science Foundation in 1950. But it is quite pertinent to mention the historical vision that both drove important elements of American foreign policy during the post-war era and provided an idealised template for future development on a global scale. Led by the "architectural" planning of Walt W. Rostow, Harvard economist and presidential advisor during the Kennedy and Johnson administrations, American foreign policy during the Cold War promised the gifts of progress and prosperity to nations that aligned themselves with the American way, and isolation or worse to those that did not. According to Rostow's famous "take off" theory, Europe had entered a new and dynamic stage of development during the seventeenth and eighteenth centuries, thanks to the accumulation and application of science. The patron saint of this epochal transition was Francis Bacon, whose philosophy explicitly linked knowledge and power, calling for the cultivation, coordination and exploitation of both scientific and artisanal knowledge and skill on a national scale. For Rostow, this was nothing short of a blueprint for what ultimately converged in the nineteenth century, as Western nation states achieved a state of continuous, long-term economic growth coupled (as Rostow's heir Joel Mokyr continues to insist) with the rise of increasingly democratic, liberal societies. And according to Rostow and his followers, this, in turn, could further provide a blueprint for "developing" nations around the globe. If these, mostly former colonial countries, could be coached through the various stages spelled out by Rostow and echoed in George Basalla's famous historical model of science and technology transfer, global progress and the worldwide victory of liberal democracy were assured. ${ }^{13}$

Though Rostow subtitled his famous book "a non-communist manifesto", the core notion of materially grounded progress can be traced back at least to Das Kapital, which Marx introduced by claiming that "[t]he country that is more developed industrially only shows, to the less developed, the image of its own future". ${ }^{14}$ But Marx and his sympathetic readers also recognised the clear presence of a rather different relation between Western capitalism and the colonies on which its growth fed-an alternative vision that was formally enunciated by many of Rostow's critics under the banner of "dependency theory". Here, the image of linear, unidirectional progress was replaced by a scheme that distinguished between the dominant centre and exploited periphery, which heavily weighted the ongoing process of circulation and exchange in favour of the industrial West. ${ }^{15}$

It was this oppositional geography of powerful centre and subjected, subaltern periphery, along with the attendant understanding of science and technology as manifestations and tools of Western domination, that formed the heart of much post-colonial and post-modern critiques of the history of "European expansion". ${ }^{16}$ Recall the argument of Edward Said's Orientalism - that the "science" of orientalism was responsible for historically and culturally reconstituting the image of nonEuropeans as exotic "others".Consider, further, the full title of historian Michael Adas' important study: Machines as The Measure of Men: Science, Technology 
and Ideologies of Western dominance. ${ }^{17}$ In both these cases, "science" is portrayed as a western phenomenon and, as such, in harmoniously supportive alliance with the West's ideology of cultural superiority.

Of note is that the discipline of history experienced dissatisfaction with Rostowian modernism during the 1970s on a scale that extended beyond adherents of both post-modernism and post-colonialism. In a fascinating essay that examines the rise of micro-history as a respected and revelatory mode of historical analysis, Carlo Ginsburg describes how-at the very height of Braudel's reputation in the 1970s for having cemented the importance of longue durée history (recall my reference to Braudel in the introduction of this essay) - a number of his more prestigious acolytes (Pierre Chaunu, François Furet, and Jacques Le Goff) simultaneously voiced their explicit rejection of Rostow and the kind of modernist vision that supported his prescriptive interpretation of history. Contemporary political and economic unrest, along with environmental and post-colonial critiques of the status quo, they argued, had severely discredited the assumptions undergirding such prophecies of progress. Historiographically, this helped make room for alternative experiments (as Ginsburg refers to his own work) in historical analysis, including a focus on individual case studies whose very uniqueness promised to reveal a more general truth that larger-scale serial and quantitative histories missed by averaging out exceptions and the exceptional. ${ }^{18}$

In this context of polarisation and fragmentation, many historians of science responded by joining like-minded sociologists and philosophers who turned away from classical modernist notions which equated science with objectivity and universal truth. Options ranged from considering western science as only one knowledge system among many and the move toward micro-studies that examined the local settings and practices out of which scientific knowledge is constructed. ${ }^{19}$ As important and stimulating as the move toward localism has proven in the history of science, however, two important challenges need to be addressed. The first is that, no matter how local the origins of scientific knowledge, modern science seems to possess validity that extends far beyond that point; Newton's laws seem to hold not only in London, but in Beijing, Lima, and Dar es Salaam as well. Without abandoning the much needed, detailed attention that micro-studies give to the unique circumstances and negotiations locally responsible for the historical development of science, we need also to pose the question of how one can trace the move from local to the seemingly universal character of scientific methods and knowledge. The second challenge, especially pertinent to those studies which take a relativist stance, is that western science does indeed seem to be intimately connected with the history of (at least) material progress.

Examining the answers to these challenges brings us to the ways in which the concept of circulation has recently been refigured as a vehicle of historical interpretation and to an appreciation of how local exchanges have garnered increasing attention as productive nodes in the circular networks through which historical developments are constituted. The rest of this essay examines how answers to the two challenges mentioned above are informed by these two intimately connected foci of attention. The following section offers a discussion of recent work on circulation, drawn from both global history and the history of science, in order to delineate what sorts of issues its current uses raise and resolve, and to highlight the 
benefits of furthering the integration of these two sub-disciplines. The section thereafter offers a similar analysis of terms such as Pratt's "contact zone" that direct our attention toward the importance of local exchanges as sites of analytical consequence.

\section{Circulation and the Dynamics of Productive Networks}

The historical and historiographical equation of circulation with diffusion of western knowledge and values to the rest of the world was supported by the complementary vision of non-western regions as traditional and static (at least) prior to the stimulus for change that attended colonialism. Circulation's story could thus be told as a very real tale of physical movement afforded by the introduction of modern-that is, borne of western technological advances-modes of transportation, such as railroads, and other colonial infrastructures that helped alter both the local land- and mindscapes of colonised areas and peoples. But such an oppositional view, which pits modern western mobility and progress against non-western cultural and material stasis, does not bear up under scrutiny. Rather, as demonstrated by a number of recent historical studies of South Asia, cultural and commercial dynamism were among the most salient characteristics that early modern Europeans encountered when they travelled to this part of the world. ${ }^{20}$ To help give explanatory voice to such indigenous dynamism, the editors of a recent collection of essays on the subject introduce their volume with the following discussion:

In this volume, circulation will... refer to more than the movement to and fro of men and goods between one part of the [Asian] subcontinent and another. Apart from men and goods, many other items circulate in society (and between a given society and other societies): information, knowledge, ideas, techniques, skills, cultural productions (text, songs), religious practices, even gods. Circulation is different from simple mobility, inasmuch as it implies a double movement of going forth and coming back, which can be repeated indefinitely. In circulating, things, men and notions often transform themselves. Circulation is therefore a value-loaded term which implies an incremental aspect and not the simple reproduction across space of already formed structures and notions.

By focusing on the historical development of South Asia as built on long-standing and evolving networks of travel that were themselves formed, reformed and sustained by an unending series of local exchanges - be they of a political, commercial, intellectual, religious or hybrid nature-the stage is set for "linking different parts of the subcontinent to one another and the subcontinent as a whole to the wider world". ${ }^{21}$

The history of science can be of great help in such an enterprise because of the constitutive role science played in linking various other sorts of endeavours and various parts of the world (see the other essays in this issue for examples), as well as for the methodological clues recent work in the field can provide the broader field of history. ${ }^{22}$ An excellent case in point is an article written by Joseph O'Connell which accounts for the seeming universality of science by the circulation of measuring devices and systems of calibration that embody socially negotiated standards. 
What makes the global distribution of increasingly uniform scientific production and dissemination-as well as a myriad of other forms of geographically distributed systems of material or administrative production and consumption-possible, O'Connell argues, is the widespread circulation and acceptance of metrological systems, standards and measuring devices such as the metric system, the ohm and carefully calibrated instruments for measuring phenomena that range from earthquakes to body fat content. ${ }^{23}$ But neither the establishment nor diffusion of such standards is a tribute to nature; neither, therefore, can the growth of scientific knowledge simply be attributed to the "voice of nature". Rather they are the achievement of hard-won historical chains of social (one might also read here intellectual, commercial and political) negotiations. Once in place, however, agreed upon standards and the apparatus and procedures which put them to work enable three closely related things that are too often attributed to the universal validity of naturally grounded scientific knowledge: the subordination, replacement or translation of local procedures, measuring systems and units by methods, systems and measuring devices which are largely Western in origin; the geographically distributed generation of comparable findings and products; and communication among geographically disparate, but metrologically standardised locations. Laboratories around the globe thus appear increasingly as "placeless places" and the content of scientific knowledge seems essentially immune to the exigencies of local cultures. ${ }^{24}$ Is it too much here to speak of the "empire of science"?

Translation is a helpful term for understanding this evolution of circumstances, as it can be taken to refer both to movement from one place to another and to transformative communication between languages, cultures or social and occupational groups. So too is accumulation, as it focuses our attention on the various objects and forms of capital and expertise which historically became concentrated in places and spaces whose dominant inhabitants were subsequently able to build networks within which translation projects could be profitably managed. The historic combination of transformative travel and growth of centres in which the accumulation of goods, knowledge, skills and capital could be translated into a means of building and governing regional, interregional and global networks of (knowledge) production and exchange, allows us to chart a complex course of history in which voyages of exploration, commercial ventures, religious missions, military expeditions, diplomatic initiatives and any number of hybrid endeavours were implicated in and contributed to the interactive and interpenetrating realms of social, political and economic developments, as well as to cycles of knowledge, material and cultural production and consumption.

On one hand, this takes us back to Marx's fundamental insights regarding the establishment of centres of accumulation and global trading networks that attended the rise of capitalism. On the other hand, it can be seen to provide a global theatre in which to situate a history of science shaped by the principle of causal symmetry between scientific content and broad-based context. An influential, if controversial, model for this approach can be found in the work of the sociologist and philosopher of science Bruno Latour. Latour has sought to explain the evolving "map" of scientific development as built upon the construction of centres of accumulation whose key agents and institutions not only manage to recruit human and non-human allies into growing networks of production and exchange, but also 
maintain their status as inhabiting the centre through the circulation of standardised and standardising objects and concepts which help reform and govern that network's local spaces by their active presence. ${ }^{25}$

This process of recruitment and circulation is a thoroughly transformative process for at least three reasons. First, it lends new identities to recruitees, who / that are now defined by the way in which they can be shown to demonstrate the validity of the claim, instrument, theory or disciplinary system in question. Second, if successful, the site from which a given (group of) scientist(s) seeks to build a supportive network becomes a centre that dominates its associated periphery, prescribing the network's culture and controlling the flow of resources. Third, nature itself is reorganised as a field whose objects and (inter-)actions simultaneously support and are explained by the scientific procedures and claims that emanate from the centre.

How is this accomplished? How is a network established and held together across space and time? Here Latour depends on a refined notion of circulation. As stated, he argues that the flow of raw materials, data and knowledge claims is transformatively carried by standardised and standardising measuring and representational devices. These instruments, graphs, diagrams and texts quite palpably translate them into supportive elements of scientific production and explanation through a process of homogenising abstraction; culturally rich locations become dots on a cartographic chart, diverse populations are rendered as numerical statistics in a table and so forth. It is the circulation of these "immutable mobiles", as Latour calls them, that strengthens the network, lending its practices (at least) the patina of homogenisation and its knowledge claims the convincing appearance of universality.

Latour's model has some very compelling elements, especially the reference of science's apparent universality to the circulation of its instruments and processes of standardisation. But it also presents at least two closely related problems. First, it offers a historical image of the world (of science) as one composed of centres and peripheries. The establishment and position of these centres shift over time, to be sure, but the point remains that Latour's approach draws our attention to the machinations that go into building and maintaining this relational geography. In place of modern science's claims to objectivity - the "view from nowhere"-we are asked to focus on the construction and maintenance of a determining view from an aspiringly central somewhere. As argued by the essays in this special issue as well as by a number of other historians, however, this approach does not do full justice to the complex routes, negotiations and exchanges involved in the paths of circulation along which science, technology and global relations more generally have historically developed. ${ }^{26}$

One reason why such a centre-oriented historical geography impoverishes our understanding (and this brings us to the second problem) is that science and technology have not historically developed along the kind of homogenising lines that might be traced out by limiting our focus to histories of discovery and innovation. The historian of science and technology David Edgerton, among others, has called on us to alter our historical perspective and consider the history of science and technology as fundamentally shaped by local appropriation and adaptive use. As he convincingly argues, historians' investigative and interpretive bias toward novelty 
has actually been responsible for reading most of the developments that should garner our attention out of the picture-especially when we examine the history of science and technology as global phenomena. Most scientific and technological activity has, in fact, historically involved the local adaptation and use of extant knowledge, procedures, apparatus and artefacts. ${ }^{27}$ Alongside the apparent processes of global homogenisation and standardisation upon which analysts such as Latour focus, then, is a rich history of locally based diversification that needs to be recovered. Other historians will certainly recognise the aptness of parallel accounts in their own areas of specialisation.

In order to get at and link these stories of local production, interpretation, appropriation, and use, we need an approach that enables us to think about circulation, not as movement that has a designated centre - that is, a clear and privileged point of origin and return-but as a continuous path whose formative trajectory is constituted out of multiple points of local contact and exchange. ${ }^{28} \mathrm{We}$ can begin to see what this entails concretely by examining how historians have responded to one of the prime examples that Latour has used to illustrate his claims, a story which begins with the late eighteenth-century voyage of the French explorer Jean-François de Galaup, comte de La Pérouse, who visited the North Pacific island of Sakhalin in 1787 as part of his mission to map the Pacific. ${ }^{29}$ Briefly, as Latour relates, La Pérouse and his men landed on the shore of Sakhalin, not knowing whether it was an island or a peninsula, but very eager to find out. The "Chinese savages" (sic) they encountered on the beach proved refreshingly able to communicate in geographical terms; one older native drew a map of Sakhalin in the sand, which washed away with the incoming tide, while a younger man attempted to draw a chart on paper that indicated distances in terms of canoe travel. ${ }^{30}$ The notes that La Pérouse made of such encounters and managed to send back to Paris were subsequently translated into the more abstract language of European cartography, represented on charts and globes that standardised this accumulated knowledge and made it mobile. Now stable enough to undertake effective travel, these "immutable mobiles" served simultaneously as symbols of European superiority - they were, after all, the combined product of French imperial endeavour and scientific prowess-and as vehicles for further investigation, knowledge production, conquest and control.

While accepting Latour's assertion that the historical drama of European cartography in the eighteenth century is simultaneously and inseparably a story of knowledge production and imperialism, the historian Brett Walker examines how similar techniques were used by Japanese explorers and cartographers in the early nineteenth century to map Japan's northern border lands, with a number of consequential effects. On one hand, the process aided Edo's own imperialistic urges vis à vis its periphery. Cartographic knowledge of the north situated "outlying" areas on a grid that placed the Japanese capital at its centre and opened this periphery to increased surveillance and control. So too were local inhabitants "banished" from this depopulated world of cartographic representation, relegated to the confines of ethnographic studies and marginal exoticism, bound to be seen as inferior to their modern Japanese counterparts. ${ }^{31}$

On the other hand, Walker argues, "European" cartography also served Japan as a weapon with which to stave off the imperial designs of other western powers. Urged on especially by increasing evidence of Russian interest in Japan's northern 
border region and the unexpected presence of foreign ships along its coast and at the port of Nagasaki, a number of surveying missions were launched to map and fortify Japan against unwanted incursions. ${ }^{32}$ The "European science" of cartography can thus, Walker explains, be seen as a double-edged sword: on one hand, extending the reach of European imperial power and scientific culture; on the other, providing "peripheral" powers such as Japan the ability to withstand external military threats and to "modernise" without succumbing to foreign imperial controlindeed, Japan could more effectively further its own imperial designs. (The terms in quotation marks are Walker's.) At the very least, this conjures an image of multicentric and tension-filled circulation.

As insightful as Walker's historical analysis is, it could go farther in its qualification of Latour's argument. To begin, we need to reconsider the underlying claim that modern cartography is in fact a fully European invention. This is not only a question of tracing its long-term debt to Ptolemy (too often co-opted by adherents of Western Civilisation) and his Byzantine commentators. ${ }^{33}$ Historians have also endeavoured to show how seemingly European developments in cartography and related fields were themselves often culturally hybrid in practice. ${ }^{34}$ This more nuanced method is closely linked to the second problem with Latour's approach mentioned above: that his centre-oriented historical geography draws our attention away from the specifics of local exchanges, whose negotiations and appropriations are crucial ingredients in the content, direction and consequences of circulationwhether we are speaking of the history of science or history more generally. Even the slightest attention to local detail would save us, for example, from a narrative that labels the Ainu inhabitants of Sakhalin "Chinese savages". More importantly, attending with greater care to the details of encounters such as those which took place on the beach of Sakhalin opens us to a much richer understanding of the circumstances, work and consequences involved in intercultural exchange, which in turn allows for a recognition of the existence of "inverse dependence" (that is, the dependence of visitors such as European explorers and traders on local assistance in meeting ambient challenges-a point to which I return) and the processes of local appropriation.

In the name of symmetry, however, we need to go beyond thinking of (non-western) appropriation solely as a counterpart to (western) innovation. Thanks to analyses by historians and anthropologists such as Michael Bravo, we are in a better position to recognise the transformations that attended La Pérouse's acceptance of Sakhalinese Ainu gifts of knowledge, which culminated in the appearance of "European" maps, as involving an extended and highly ritualised process of appropriative translation. ${ }^{35}$ To begin with the level of empirical description, Bravo's critique (among others') reveals the need for more careful attention to historical detail. In contrast to Latour's entertainingly light presentation of a one-off encounter, La Pérouse's party was in Sakhalin waters for some seven weeks, during which time a number of exchanges with locals took place. This was not only a matter of obtaining geographically and ethnographically relevant information, but also of obtaining mundane necessities and hoping to establish friendly relations as a basis for future interactions. La Pérouse was, in other words, highly dependent on local communication, good will and support. While Latour does not at all deny this important point, he is interested to show how cycles of accumulation and calculation fed the 
growing strength of Western science as a means to overcome such dependence, to gain and maintain mastery over the world. In his rush to draw our attention to these global cycles, he fails to examine the local processes of translation whereby the material and knowledgeable goods offered by native traders and informants were made commensurable with La Pérouse's interests and expectations. ${ }^{36}$ That is to say, he remains silent about the "field practices" employed by western visitors such as La Pérouse that rendered local products consumable by fashioning them as commensurable with the familiar grid of expression and use. The significance of this analysis, as developed by Bravo, is that it reveals a crucial irony: the subsequent incommensurability that was claimed to exist between "universally valid" western science on one hand, and local knowledge traditions and cultures on the other, was actually dependent on prior and quite local processes of exchange and commensuration.

While such a critical approach helps restore the importance of attending to local exchanges, it remains focused on the relations between Europeans and "others". We know, however, that the Ainus of Sakhalin did not live in a state of splendid isolation prior to their contact with La Pérouse. Rather, his visit must be set in the context of other long-standing and on-going contacts which direct our attention to the economies of intra-Asian and Pacific exchanges. Why should we assume that the arrival of a European somehow constitutes a turning point in history? How else can we, for example, explain the cartographic knowledge and abilities of local fishermen, who had never before been in touch with the West? By shifting our axis of investigation away from an exclusive focus on encounters between "the West and the rest" toward one that places an emphasis on the local in the context of a non Eurocentric world, we are in a better position to appreciate the closely linked histories of scientific development and global exchange. While such a move must not lose sight of shifting concentrations of power and the consequent lack of balance in such exchanges and development, it will surely lead to a more nuanced and sophisticated understanding. ${ }^{37}$

\section{Zooming in on the Local}

Contending with historical developments of global dimension we have seen, requires us to weave our way through the complexities of local settings and the exchanges they housed. As stated in the introduction, the term chosen to denote sites of local exchange in this special issue is "contact zone", which was first developed and brought to public attention by Mary Louise Pratt as part of her study on imperial travel literature. This is not to say that the project represented here is precisely the same as Pratt's. A primary difference is that she and many of those who (critically) use the term are interested in the identity formation of human actors - of "travellers and travellees", as she puts it, especially as reflected in travel literature. ${ }^{38}$ The focus of the essays that follow here is not only on how "contact" affected the identities and relations of humans, but the identities and relations of a whole slew of objects and phenomena that somehow embodied or conveyed knowledge claims. Our interest in "contact zone" is also a bit more specified in that we aim to expose the intimate interconnectedness between the history of science and global history more generally. Furthermore, as will become clear in what follows, it is cer- 
tainly not the case that other terminology has not and cannot be used productively to make similar points. Rather, reliance on the term "contact zone" here is intended to open discussion on a number of points raised below and examined in the other essays of this issue, while providing an element of terminological continuity.

With this said, it is helpful to begin with Pratt's own definition, taken from her book Imperial Eyes: Travel Writing and Transculturation:

"[C]ontact zone" is an attempt to invoke the spatial and temporal co-presence of subjects previously separated by geographic and historical disjunctures, and whose trajectories now intersect. By using the term "contact", I aim to foreground the interactive, improvisational dimensions of colonial encounters so easily ignored or suppressed by diffusionist accounts of conquest and domination. A "contact" perspective emphasises how subjects are constituted in and by their relations to each other. It treats the relations among colonisers and colonised, or travellers and "travellees", not in terms of separateness or apartheid, but in terms of co-presence, interaction, interlocking understandings and practices, often within radically asymmetrical relations of power.

Local exchanges, Pratt is keen to point out, were shared experiences that entangled parties in local economies of interactive translation which cannot simply be mapped onto a grid of relations drawn from the level of macro-analysis. No matter how asymmetrical overall relations of power might have been between the parties involved, the local quest to satisfy needs and desires was bound to tip the scale in historically surprising and formative ways. Thus we must see contact zones as spaces in which asymmetrical relations might be (at least temporarily) suspended or modified in favour of more local economies of dependence and interests. This allowed for a kind of geographically based displacement, in which local needs and desires shaped exchanges in ways that did not always reflect developing power relations writ large and which afforded results that could have a highly productive impact on scientific (or other "western") development(s).

The focus on "co-presence" and the locally specific nature of economies of exchange marks Pratt's perspective, like that adopted here, as importantly different from two other predominant historical discourses. The one, already discussed in this essay, explains history through the lens of diffusionism, viewing science as a western phenomenon that subsequently spread-for better or worse-to the rest of the world. Sophisticated versions of this approach continue to be influential within the related disciplines of global history and the history of science, carried by a recognition that science and technology were indeed prime vehicles in the march of western imperialism. A good example of this is Matthew Edney's Mapping an Empire: The Geographical Construction of British India, 1765-1843, whose narrative is structured by his claim that "the British did science, the Indians did not". ${ }^{39}$

The second approach is comparative history, which tends similarly to distinguish between modern science as a product of western culture and developments in other parts of the world. The locus classicus of this approach in the history of science is the work of Joseph Needham (who we met above as an early and influential members of the history of science community at Cambridge), who built a longrunning program of historical investigation around the question of why the 
Scientific Revolution (seen as having given birth to modern science) occurred in Western Europe rather than in China. ${ }^{40}$ Comparative history has made an impressive resurgence in the past years, especially among economic historians. Consider, for example, Patrick O'Brien's essay with which this essay began, that calls on us to adopt comparative history as a primary vehicle for grappling with world history, and books such as Kenneth Pomeranz' The Great Divergence: China, Europe and the Making of the Modern World Economy. ${ }^{41}$

Comparative history sets out to chart similarities and, especially, differences, which are then used to account for regional divergences. While appreciating the professional mastery involved in such endeavours, we need also to acknowledge that such an explanatory matrix is simply not geared toward investigating the kinds of interactions, exchanges and hybridising processes that spread out from local contact zones to inform the development of science and global history more generally. And, once we grant the role played by local exchanges and circulation in the very constitution of scientific development and historical development more generally, it becomes more difficult to rest content with a comparative approach that begins by identifying similarities and differences rather than confluences and mutually formative interaction.

The term "contact zone" is especially felicitous along these lines in that it represents a pronounced alternative to more traditional talk about encounters on the "frontier". While certain locations, peoples and phenomena that western explorers and traders encountered were indeed new to them, the term "frontier" reflects their geographical perspective and feeds the kind of historical narrative that focuses on "discovery" and "expansion"; we have only to think of the Turner thesis, with its connection to "manifest destiny", or Vannevar Bush's description of science as the "endless frontier" to see the seductive dangers entailed in taking this metaphor seriously. ${ }^{42}$ Recent historiographical directions and discussions have explicitly posed the question of just how to configure what we might call post-frontier studies. A brief mention of one of the major issues at stake in these discussions, which also points to the possible attractiveness of alternative terminology, adds importance nuance to our understanding of the "contact zones" examined in the essays that follow this one. At stake is how to configure retrospectively the places and spaces within which different peoples and cultures encountered each other; where, in other words, to place one's analytical emphasis. Should such sites be construed as "middle ground" (provisionally open spaces of (inter-) cultural improvisation); as "native ground" (inhabited spaces in which colonising foreigners might be seeking to situate themselves and their practices; or as "borderlands" (dynamically interactive spaces in which borders of various types and porosity are nonetheless present)? ${ }^{43}$

The historian Richard White developed his concept of the "middle ground" as a way to understand the interactions between Europeans and North American natives around the Great Lakes region from 1650-1815. Recovering this place "in between", where mutual accommodations transformed creative misunderstandings into new meanings and shared practices on the part of both European settlers and indigenes, White's history pays tribute to the lived experiences of people whose great distance from metropolitan centres of power afforded them the space (quite often borne of necessity) to create hybrid modes of (cultural) existence. A soon-toappear essay by James Delbourgo develops the concept of "middle ground" as a 
way to describe the Caribbean region during the eighteenth century as a context through which individuals could travel with important consequences for both material and knowledge production. Key for Delbourgo is the fact that, while a number of variously competitive, cooperative and unequal groups populated or passed through the region, no single cultural, commercial or political power was sufficiently dominant to determine rules of engagement. This context, in which sociocultural, commercial, political and military relations were constantly under negotiation, provided relatively open opportunities for entrepreneurial individuals to move and mediate between the resources and interests of various sites and groups within and beyond the region. It was often out of such mediated linkages that locally based knowledge, skills and materials were also set in motion, leading to productive results in a variety of fields that included natural history, chemistry and the manufacture of products such as dyes which had an enormous impact on European manufacture more generally. ${ }^{44}$

The complexities of Delbourgo's case remind us that sites of local exchange, no matter how we choose to label them, are historically irreducible to a single model. In addition to the stereotypical images of European voyagers encountering naked natives on a beach or sumptuously dressed potentates in lavish court settings, are a myriad of other sites that require our attention. Quite often these were multicultural zones rather than isolated meeting places between two groups. They could also be highly urbanised, such as the entrepôt of Canton, which features in recent work by the historian of science Fa-Ti Fan. ${ }^{45}$ To deal with such historical complexities, Fan argues in favour of employing the term "cultural borderlands" rather than what he sees as the more undifferentiated term "contact zone". In order to get at the kinds of exchanges situated in places like Canton that fed the production of scientific knowledge, he explains, it is necessary to recognise and attend to three things: "the cultural aspect (including material culture) of encounters"; the fact that, no matter how contingent, flexible or unnatural, borders did indeed exist and had "real effects on historical actors"; and the crucial and constant role of mediators and go-betweens. ${ }^{46}$ By bringing these three analytical elements together, Fan is able to weave an intricate and convincing exposition of how British and other foreigners accrued natural knowledge about China by combing the marketplaces of Canton, where they learned from local merchants and the objects they sold; by visiting local gardens and ports, where they conversed with gardeners and fishermen, learning about local plants and animals; and by interacting with Chinese customs officials who were long accustomed to classifying and accounting for the goods that passed under their scrutiny. It was this highly urbanised space that provided an immensely fertile field for Europeans who sought to enhance their knowledge of nature in China-a far cry from the stereotypical image of European explorers braving the dangers of virgin jungles in search of scientific understanding, aided (at best) by native servants who had little of substance to say.

The above discussion also indicates that we need to amend another stereotypical vision of the history of science, one that parallels a view of imperialism as built on the importation of raw materials from the colonies which were then refined and processed in Europe for further export. We see here, rather, a situation in which the knowledge and materials on which Europeans drew for the advancement of natural history, chemistry and a number of other fields were already locally processed 
and refined, thanks to long-standing networks of local exchange and circulation. This leads to a number of consequences of general import, with which this essay concludes.

\section{Conclusion}

This essay began and ends with a call to investigate and integrate the history of science as a mutually constructive element of global history by simultaneously situating our inquiries in the contexts of globally extensive circulation and locally intensive theatres of exchanges. Along the way, we have also seen the kinds of cross-fertilisation that have historically helped undergird our changing understanding of scientific development and its place in the world-from visions of western superiority and (the need for) the global diffusion of western science, to relativist histories borne of disenchantment with this view and its attendant promises of material and moral progress, to current efforts of reintegration built on a non-Eurocentric basis. We have further seen how each of these visions considers the seemingly evident claim of science's universal validity-as a reflection of objective truth, a manifestation and tool of western hegemony, and as the circulation of standardised and standardising devices and representations within complex networks of local negotiation and adaptation. This final view brings with it a number of important historical insights, three of which are worth mentioning by way of conclusion and as a further introduction to the essays that follow.

First is the fact that, when Europeans began taking to the high seas and far-flung roads of global exploration and trade, they stepped and sailed into already extant networks of-sometimes local, sometimes quite extended and sophisticatedexchange. While their increasingly active presence altered the dynamics and trajectories of these networks, this is a very different conception of history from one that speaks of European "discoveries" and new frontiers. As ironic as it might seem in the context of a discussion amongst historians, this invites us to re-insert time as a fundamentally ongoing dimension of our analyses, as the fourth dimension (if you will) of the historical geography of circulation. That is to say, it counters the traditional tendency to think and analyse in culturally loaded terms of points of temporal origins.

Second, as we have seen, the variety of local configurations in which encounters and exchanges took place requires our attention, precisely because they and the activities they housed were constituent of the path taken by circulation. This is so, not only for the history of science, but for the history of socio-political, cultural and economic history more generally. Perhaps better put, our analysis of the interactions that both gained shape and substance from and lent them to specifically configured local contexts around the world provides conclusive evidence for the interlocking nature of developments in various regions of the world (this is not only a call to reconsider the historical relations between Europe and its former colonies) and in these various subfields of global history.

Third, what makes this sort of analysis so crucial is that these variegated local settings that fed the circulatory process of knowledge production were simultaneously the contexts of local appropriation and adaptation. That is to say, at one and the same time circulation etched out paths of (knowledge) production and local 
consumption and use-often the kind of change that has all too easily been characterised as progress resulting from the diffusion of western science and technology. But we need to take this realisation one step farther and recognise that these multi-tracked paths of circulation were truly global in nature. Appropriation was not a phenomenon limited to colonies and "developing countries". It encompassed the entire globe, enveloping all regions and all aspects of history within its purview. The history of science is thus a global history, both because it is embedded in the broader context of history, but also because it has no privileged place of origin: it is a constantly developing consequence of circulation.

Here we might borrow a concept from historians who counter essentialist definitions of Europe with one that analyses it as an "emergent outcome" of history. Science, to draw a parallel, is not liable to any essential definition. Rather, it and the world of which it is a part are emergent outcomes of an intricately detailed history of local exchanges and circulation. ${ }^{47}$ To integrate the history of science and global history, then, we need to capture the ways in which local exchanges and global circulation simultaneously shaped scientific and technological developments and coconstructively integrated them with the broader developments of political, economic and cultural history. Only then will we be able to appreciate the role played by science and technology in shaping modernity.

\section{Bibliography of Works Cited}

. A College Program in Action: A Review of Working Principles at Columbia College. New York: Columbia University Press, 1946.

- General Education in a Free Society. Cambridge: Harvard University Press, 1945.

Adas, Michael. Machines as the Measure of Man: Science, Technology and Ideologies of Western Dominance. Ithaca: Cornell University Press, 1989.

Alder, Ken. "A Revolution to Measure: The Political Economy of the Metric System in France". In Values of Precision, edited by M. Norton Wise. Princeton: Princeton University Press, 1995.

Allardyce, P. Gilbert. "The Rise and Fall of the Western Civilization Course". The American Historical Review 87 (1982): 695-725.

Ashcroft, Bill, Gareth Griffiths, and Helen Tiffin. The Post-Colonial Studies Reader. London: Routledge, 1995.

Basalla, George. "The Spread of Western Science”. Science 156 (1967): 611-622.

Billington, Ray. Frederick Jackson Turner: Historian, Scholar, Teacher. New York: Oxford University Press, 1973.

Bogue, Allen. Frederick Jackson Turner: Strange Roads Going Down. Norman: University of Oklahoma Press, 1998.

Braudel, Fernand. La Méditerranée et le monde Méditerranéen à l'epoque de Philippe II. Paris: Armand Colin, 1949.

Bravo, Michael. "Ethnographic Navigation and the Geographic Gift". In Geography and Enlightenment, edited by David Livingstone and Charles Withers..Chicago: University of Chicago Press, 1999.

Brioch, John. "Engineering the Empire: British Water Supply Systems and Colonial Societies, 18501900". Journal of British Studies 46 (2007): 346-65.

Brown, Matthew. "Richard Vowell's Not-So-Imperial Eyes: Travel Writing and Adventure in NineteenthCentury Hispanic America". Journal of Latin American Studies 38 (2006): 95-122.

Bush, Vannevar. Science: The Endless Frontier. A Report to the President by Vannevar Bush, Director of the Office of Scientific Research and Development, July 1945. Washington: United States Government Printing Office, 1945. 
Chamberlain, Joseph. "The True Conception of Empire”. Annual Royal Colonial Institute Dinner, Hotel Metropole, 31 March, 1897.

Chaunu, Pierre. Séville et l'Atlantique, 1550-1650. Paris: S.E.V.P.E.N., 1959.

Cunningham, Andrew and Perry Williams. "Decentring the 'Big Picture': The Origins of Modern Science and the Modern Origins of Science". British Journal for the History of Science 26 (1993): 407-32.

Dalrymple, William. The White Mughals: Love and Betrayal in Eighteenth-Century India. London: HarperCollins, 2002.

Delbourgo, James and Nicholas Dew, eds. Science and Empire in the Atlantic World. New York: Routledge, 2008.

Delbourgo, James. "Fugitive Colours: Shaman's knowledge, Chemical Empire and Atlantic Revolutions". In The Brokered World: Go-betweens and Global Intelligence, 1770-1820, edited by Simon Schaffer et al., forthcoming.

Dening, Greg. Beach Crossings: Voyages Across Times, Cultures and Self. Melbourne: Melbourne University Publishing, 2004.

Dennis, Michael Aaron. "Historiography of Science: An American Perspective". In Science in the Twentieth Century, edited by John Krige and Dominique Pestre. Amsterdam: Harwood Academic Publishers, 1997.

—. "Reconstructing Sociotechnical Order: Vannevar Bush and US Science Policy". In States of Knowledge: The Co-production of Science and Social Order, edited by Sheila Jasanoff. London: Routledge, 2004.

Edgerton, David. The Shock of the Old. Oxford: Oxford University Press, 2006.

Edney, Matthew. Mapping an Empire: The Geographical Construction of British India, 1765-1843. Chicago: University of Chicago Press, 1997.

Fan, Fa-Ti. "Science in Cultural Borderlands: Methodological Reflections on the Study of Science, European Imperialism and Cultural Encounter". East Asian Science, Technology and Society 1 (2007): 213-31.

- British Naturalists in Qing China: Science, Empire and Cultural Encounter. Cambridge: Harvard University Press, 2004.

Frank, Andre Gunder. Capitalism and Underdevelopment in Latin America. New York: Monthly Review Press 1967.

Gerona, Carla. "Review of Weber, David J., Bárbaros: Spaniards and Their Savages in the Age of Enlightenment and Hackel, Steven W., Children of Coyote, Missionaries of Saint Francis: IndianSpanish Relations in Colonial California, 1769-1850 and Barr, Juliana, Peace Came in the Form of a Woman: Indians and Spaniards in the Texas Borderlands. H-Atlantic, H-Net Reviews. January, 2009. URL: http://www.h-net.org/reviews/showrev.php?id=22897.

Ginsburg, Carlo. "Microhistory: Two or Three Things that I Know about It". Critical Inquiry 20: 10-35.

Gordon, Linda, David Hunt, and Peter Weiler. "History as Indoctrination: A Critique of Palmer and Colton's History of the Modern World". The History Teacher 21 (1987): 53-103.

Guelke, Leonard and Jeanne Kay Guelke. "Imperial Eyes on South Africa: Reassessing Travel Narratives". Journal of Historical Geography 30 (2004): 11-31.

Hotstetler, Laura. Qing Colonial Enterprise: Ethnography and Cartography in Early Modern China. Chicago: University of Chicago Press, 2001.

Jacob, Margaret. Scientific Culture and the Making of the Industrial West. New York: Oxford University Press, 1997.

La Pérouse, Jean-François de Galaup, comte de. The Journal of Jean-François de Galaup, comte de La Pérouse, 1785-1788, 2 vols., edited and translated by John Dunmore. London: Hakluyt Society, 1994-1995.

Lach, Donald. Asia in the Making of Europe. Chicago: University of Chicago Press, 1965.

Latour, Bruno. "Drawing Things Together". In Representation in Scientific Practice, edited by Michael Lynch and Steven Woolgar. Cambridge: MIT Press, 1990.

- Science in Action: How to Follow Scientists and Engineers through Society. Cambridge: Harvard University Press, 1988.

Leask, Nigel. Curiosity and the Aesthetics of Travel. Oxford: Oxford University Press, 2004.

Liss, Robert. "Frontier Tales: Tokugawa Japan in Translation". In The Brokered World: Go-betweens and Global Intelligence, 1770-1820, edited by Simon Schaffer et al., forthcoming. 
Livingstone, David. Putting Science in its Place: Geographies of Scientific Knowledge. Chicago: University of Chicago Press, 2003.

MacLeod, Roy. "Introduction". Nature and Empire: Science and the Colonial Enterprise. Osiris 15 (2000): 1-13.

Markovits, Claude, Jacques Pouchepadass, and Sanjay Subrahmanyam, eds., Society and Circulation: Mobile People and Itinerant Cultures in South Asia, 1750-1950. Delhi: Permanent Black, 2003.

Marx, Karl. Capital. London: Pelican Books, 1976.

Mayer, Anna K. "Setting up a Discipline: Conflicting Agendas of the Cambridge History of Science Committee, 1936-1950". Studies in the History and Philosophy of Science 31 (2000): 665-89.

Misa, Thomas and Johan Schot. "Inventing Europe: Technology and the Hidden Integration of Europe". History and Technology 21 (2005): 1-19.

Mokyr, Joel. The Gifts of Athena: Historical Origins of the Knowledge Economy. Princeton: Princeton University Press, 2002.

Needham, Joseph et al. Science and Civilisation in China, 7 vols. Cambridge: Cambridge University Press, 1954-2004

O'Brien, Patrick. "Historiographical Traditions and Modern Imperatives for the Restoration of Global History". Journal of Global History 1 (2006): 3-39.

O'Connell, Joseph. "Metrology: The Creation of Universality by the Circulation of Particulars". Social Studies of Science 23 (1993): 129-173.

Palmer, Robert Roswell and Joel Colton. History of the Modern World. New York: Alfred Knopf, 1950.

Pomeranz, Kenneth. The Great Divergence: China, Europe and the Making of the Modern World Economy. Princeton: Princeton University Press, 2000.

Pratt, Mary Louise. "Arts of the Contact Zone". Profession 91 (1991): 33-40.

- Imperial Eyes: Studies in Travel Writing and Transculturation. London: Routledge, 1992.

Roberts, Lissa, Simon Schaffer, and Peter Dear, eds. The Mindful Hand: Inquiry and Invention from the Late Renaissance to Early Industrialization. Amsterdam: Royal Dutch Academy of Sciences, 2007. (Available online: http:/www.knaw.nl/cfdata/publicaties/detail.cfm?boeken_ordernr=20041102.)

Said, Edward. Orientalism: Western Conceptions of the Orient. New York: Pantheon Books, 1978.

Schaffer, Simon et al. The Brokered World: Go-betweens and Global Intelligence, 1770-1820, forthcoming.

Secord, James. "Knowledge in Transit". Isis 95 (2004): 654-72.

Seeley, John Robert. The Expansion of England. London, 1883.

Subrahmanyam, Sanjay. "Connected Histories: Notes Towards a Reconfiguration of Early Modern Eurasia”. Modern Asian Studies 31 (1997): 735-62.

Turnbull, David. Masons, Tricksters and Cartographers: Comparative Studies in the Sociology of Scientific and Indigenous Knowledge. London: Harwood Academic Publishers, 1999.

Turner, Frederick Jackson. The Frontier in American History. New York: Henry Holt and Co., 1920.

Vinck, Dominique. "Back to the Laboratory as a Knowledge Production Space". Revue d'anthropologie des connaissances 1 (2007): 160-5.

Walker, Brett. "Foreign Affairs and Frontiers in Early Modern Japan: A Historiographical Essay". Early Modern Japan 10 (2002): 44-62, 124-8.

Walt, W. Rostow. The Stages of Economic Growth: A Non-communist Manifesto. Cambridge: Cambridge University Press, 1960.

Yanemoto, Marcia. Mapping Early Modern Japan: Space, Place and Culture in the Tokugawa Period, 1603-1868. Berkeley: University of California Press, 2003. 


\section{Notes}

* Lissa Roberts leads the research division on "Long term development of science and technology" at the Centre for Science, Technology and Policy Studies, University of Twente. She recently edited a volume with Simon Schaffer and Peter Dear entitled The Mindful Hand: Inquiry and Invention from the late Renaissance to early Industrialisation (Royal Dutch Academy of Sciences, 2007) and has teamed up with Simon Schaffer again to edit the forthcoming volume The Brokered World: Go-betweens and Global Intelligence, 1770-1820.

1 O'Brien, "Historiographical Traditions", 6-7.

2 Braudel, La Méditerranée.

3 I refer throughout this essay to "science", but it should be noted that I do so for the sake of keeping my discussion as unencumbered as possible. In fact, the term itself has been subject to much historical analysis and debate. For readers of this essay, it is perhaps most germane to draw attention to the argument put forward in Lissa Roberts, Simon Schaffer, and Peter Dear, eds., The Mindful Hand. A major point of this collection of essays is to demonstrate that what we often discuss in terms of the histories of (theoretically driven) science and (manually driven) technology, are much more appropriately discussed in terms of the history of natural inquiry and invention, a complex history in which the work of the mind and of the hand cannot be so easily separated. Rather, their interaction has historically informed both material production and knowledge production.

4 MacLeod, "Introduction".

5 While Pratt first developed the concept "contact zone" extensively in her book Imperial Eyes, she introduced it in an earlier essay, "Arts of the Contact Zone". That "circulation" has become a major concept in the history of science is attested to by a number of facts including the selection of "the circulation of knowledge" as the organising theme for the 2004 joint conference organised in Halifax, Canada by the History of Science Society, the British Society for History of Science and the Canadian Society for History of Science. See Secord, "Knowledge".

6 Seeley, The Expansion, quotations on 10 (my emphasis) and 93.

7 Chamberlain, "The True Conception".
8 Allardyce, "The Rise", 696. The historian in question is William H. McNeill, but it should be noted that his expression was representative rather than unique. The Harvard Committee of General Education, which convened in 1943-1945, had considered entitling Harvard's version of the course "The Evolution of Free Society". General Education, xiv.

9 A College Program, 97. Quoted in Gordon, Hunt, and Weiler, "History as Indoctrination", 57.

10 Palmer and Colton, History of the Modern World. This highly successful text has gone through ten editions and has been translated into a number of other languages.

11 Cunningham and Williams, "Decentring". Quotation from http://highered.mcgrawhill.com/sites/0072316551/student_view0/ chapter7/chapter_overview.html, accessed 31 December 2008.

12 On Conant and the broader American context in which he brought the history of science to Harvard, see Dennis, "Historiography of Science". For the situation in Cambridge, see Mayer, "Setting up a Discipline".

13 Rostow, The Stages; Mokyr, The Gifts of Athena; Basalla, "The Spread".

14 Marx, Capital, preface to first edition (1867), 91.

15 On dependency theory, see, for example, the seminal work of Andre Gunder Frank, beginning with Capitalism and Underdevelopment in Latin America.

16 For a good introduction to a number of these post-colonialist texts, see Ashcroft, Griffiths, and Tiffin, The Post-Colonial Studies Reader. Of special interest here is the volume's second section (pp. 55-83), entitled "Universality and Difference", which features texts that seek to show the ways in which the claimed universality of western literature and science-including mathematics-are actually projections of western domination.

17 Adas, Machines as the Measure of Men; Said, Orientalism.

18 Ginsburg, "Microhistory". For serial history see Chaunu, Séville et l'Atlantique.

19 Turnbull, Masons, Tricksters and Cartographers; for a succinct review and bibliography of localised laboratory studies, see Vinck, "Back to the Laboratory". For the question of analysing natural inquiry around the world in terms of "knowledge systems", see the essay by Elizabeth Green Musselman in this issue.

20 For an almost novel-like description of the 
powerful dynamism that met early modern European voyagers (traders, mercenaries, and the like) to India, see Dalrymple, The White Mughals.

21 Markovits, Pouchepadass, and Subrahmanyam, eds., Society and Circulation, 2-3. It is interesting to note that one of this volume's editors, Sanjay Subrahmanyam, explicitly refers to Marx and Rostow as the fathers of the modern historical perspective "which believes that the only question worth asking is that of Who Succeeded and Who Failed on the long road to modern industrial capitalism, from a list of modern nationstates" (Subrahmanyam, "Connected Histories", 745).

22 It might be a helpful exercise, when (re-) reading the section that follows, to replace the word "science" and any associated vocabulary with vocabulary drawn from the history of political, cultural, or commercial relations. This should help demonstrate how such an approach can be adapted for analysis outside the sub-discipline of history of science.

23 O'Connell, "Metrology".

24 Ibid. For laboratories as "placeless places", see Livingstone, Putting Science in its Place, 3. For an exemplary study of the controversial "invention" and introduction of the meter as a measuring standard, see Alder, "A Revolution to Measure".

25 Latour, Science in Action, 215-57.

26 For a series of accounts that focus on the crucial role of local exchanges and mediation during the period 1770-1820, see Schaffer et al., The Brokered World.

27 Edgerton, The Shock of the Old.

28 This point is well treated in Secord, "Knowledge in Transit".

29 It should be noted from the start that this was a hybrid mission, directed simultaneously toward the production of knowledge, trade and French imperial power. In addition to his discussion of La Pérouse in chapter six of Science in Action, see Latour, "Drawing Things Together". For the original story, see La Pérouse, The Journal, vol. 2, 289-98.

30 On beach encounters, see Dening, Beach Crossings.

31 See also Yanemoto, Mapping Early Modern Japan.

32 See also Liss, "Frontier Tales". For a historiographical overview of recent discussions of Japan's borders, see Walker, "Foreign Affairs".

33 Lach, Asia in the Making of Europe, vol. I, 17 .
34 An interesting example of this approach is Hotstetler, Qing Colonial Enterprise.

35 Bravo, "Ethnographic Navigation". On the relation between innovation and appropriation, see my discussion of David Edgerton above.

36 This point is related to Nigel Leask's contrast between Latour's "geography", which considers the difference between European and "native" knowledge as one of degrees, and the kind of ethnography practiced by authors such as Mary Louise Pratt (see the next section of this essay) which considers them as different kinds. Leask, Curiosity and the Aesthetics of Travel, 19-22.

37 For a similar and quite articulate treatment of the issues discussed in this section, but in the context of the Atlantic World, see the introduction to Delbourgo and Dew, eds., Science and Empire, especially 10-15.

38 Pratt, Imperial Eyes, 7. The literature that has developed in the wake of Pratt's important work is too vast to cite. For critical examples that agree with her approach but question its specifics, see Guelke and Guelke, "Imperial Eyes on South Africa"; Brown, "Richard Vowell's Not-So-Imperial Eyes".

39 Edney, Mapping an Empire, 25. For a more recent example that focuses on engineering, see Brioch, "Engineering the Empire", in which he argues that engineering water supply systems was used by British imperialists as a tool of morality and modernity in the colonies.

40 Needham et al., Science and Civilisation in China 7 vols. Interestingly, Needham's own approach married comparison with the search for cases in which Chinese science and technology diffused westward.

41 It is worth noting that both Pomeranz and Mokyr cite Margaret Jacob's work as a primary source for their understanding of a "scientific culture" which is claimed to have informed the acceleration of industrial development in Europe. For Mokyr, this is the key to understanding the source of Europe's industrial triumphs and domination of the world in the nineteenth century. Pomeranz, The Great Divergence, 44; Mokyr, The Gifts of Athena, 30ff; Jacob, Scientific Culture.

42 Turner, The Frontier in American History; contrast Bogue, Frederick Jackson Turner and Billington, Frederick Jackson Turner. Bush, Science: The Endless Frontier; on Bush, see Dennis, "Reconstructing Sociotechnical Order". 
43 For a timely and informative discussion of this point, see Gerona, "Review".

44 Delbourgo, "Fugitive Colours".

45 Fan, British Naturalists in Qing China; idem, "Science in Cultural Borderlands". On urban settings more generally, see the essay by Stéphane Van Damme in this issue.

46 Fan, "Science in Cultural Borderlands", 2156.

47 Misa and Schot, "Inventing Europe". 